\title{
Impact of climate on eel populations of the Northern Hemisphere
}

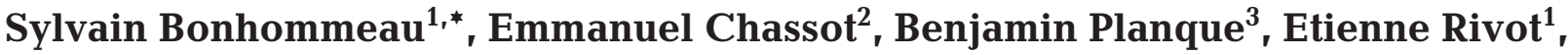 \\ Anthony H. Knap ${ }^{4}$, Olivier Le Pape ${ }^{1}$
}

\author{
${ }^{1}$ Agrocampus-Ouest, Fisheries and Aquatic Sciences Center, CS 84 215, 35042 Rennes Cedex, France \\ ${ }^{2}$ IRD - Unité de Service 007 - OSIRIS Observatoires et Systèmes d'Information des Pêches Tropicales Centre de Recherche \\ Halieutique, Avenue Jean Monnet, BP 171, 34203 Sète Cedex, France \\ ${ }^{3}$ Institute of Marine Research - Tromsø, Postboks 6404, 9294 Tromsø, Norway \\ ${ }^{4}$ Bermuda Institute of Ocean Sciences, 17 Biological Lane, Ferry Reach, GE01, Bermuda
}

\begin{abstract}
Glass eel abundances are declining worldwide. This has mostly been attributed to direct impacts of human activities such as overfishing or habitat loss and degradation, whilst the potential influence of changes in oceanic conditions has received less attention. Eel are characterized by a complex and still enigmatic life cycle that includes a trans-oceanic spawning and larval migration. The apparent synchrony in the decline of eel populations worldwide suggests that the oceanic mechanisms involved are similar for all populations. We analyse the relationships between oceanic conditions in eel spawning areas and glass eel recruitment success of the 3 most commercially important species of the genus Anguilla: A. anguilla, A. rostrata, and A. japonica. We provide evidence that the survival of eel larvae is strongly correlated with food availability during their early life stages. Over the last 4 decades, changes in the marine production related to global warming may have led to the decline of European, American and Japanese eel populations. In the Pacific and Atlantic Oceans, the shifts in the temperature regime detected in the late 1970s were followed by shifts in the recruitment regime of glass eel for the 3 species. The decrease in primary production through climate-driven processes has therefore affected the recruitment of eel populations.
\end{abstract}

KEY WORDS: Anguilla $\cdot$ Primary production $\cdot$ Climate $\cdot$ Regime shift $\cdot$ Bottom-up Resale or republication not permitted without written consent of the publisher

\section{INTRODUCTION}

Eel species have always excited a degree of fascination because of their complex and puzzling life cycle. As catadromous fish, they spawn in the open ocean (Fig. 1) — the Sargasso Sea in the case of European and American eels (McCleave 1993), and west of the Mariana Islands in the case of Japanese eels (Tsukamoto 2006). After an oceanic migration that can span thousands of kilometres and last several years (1 to 3 yr for the European eel, Schmidt 1923, Lecomte-Finiger 1994, Tesch 2003; 1 to 2 yr for the American eel, Tesch 2003; 0.5 to 1 yr for the Japanese eel, Kim et al. 2007), eels colonise continental habitats where they grow before migrating back to the open ocean for spawning.
The decline in eel populations of the Northern Hemisphere is alarming (Anonymous 2003, ICES 2006). The European eel has been listed by the Convention on International Trade in Endangered Species of Wild Fauna and Flora (CITES, www.cites.org/common/cop/14/inf/ E14i-21.pdf) regarding its current level of abundance. In the Northern Hemisphere, the abundance of juvenile eels has dramatically decreased over the last few decades: in European waters, it is now at historically low levels, i.e. less than $1 \%$ of levels in the 1980s for some recruitment time series (ICES 2006). The decline has mostly been attributed to direct impacts of anthropogenic activities such as dams, pollution and habitat loss, especially in estuaries and continental habitats (McCleave 2001, Feunteun 2002, Dekker 2003, Tat- 

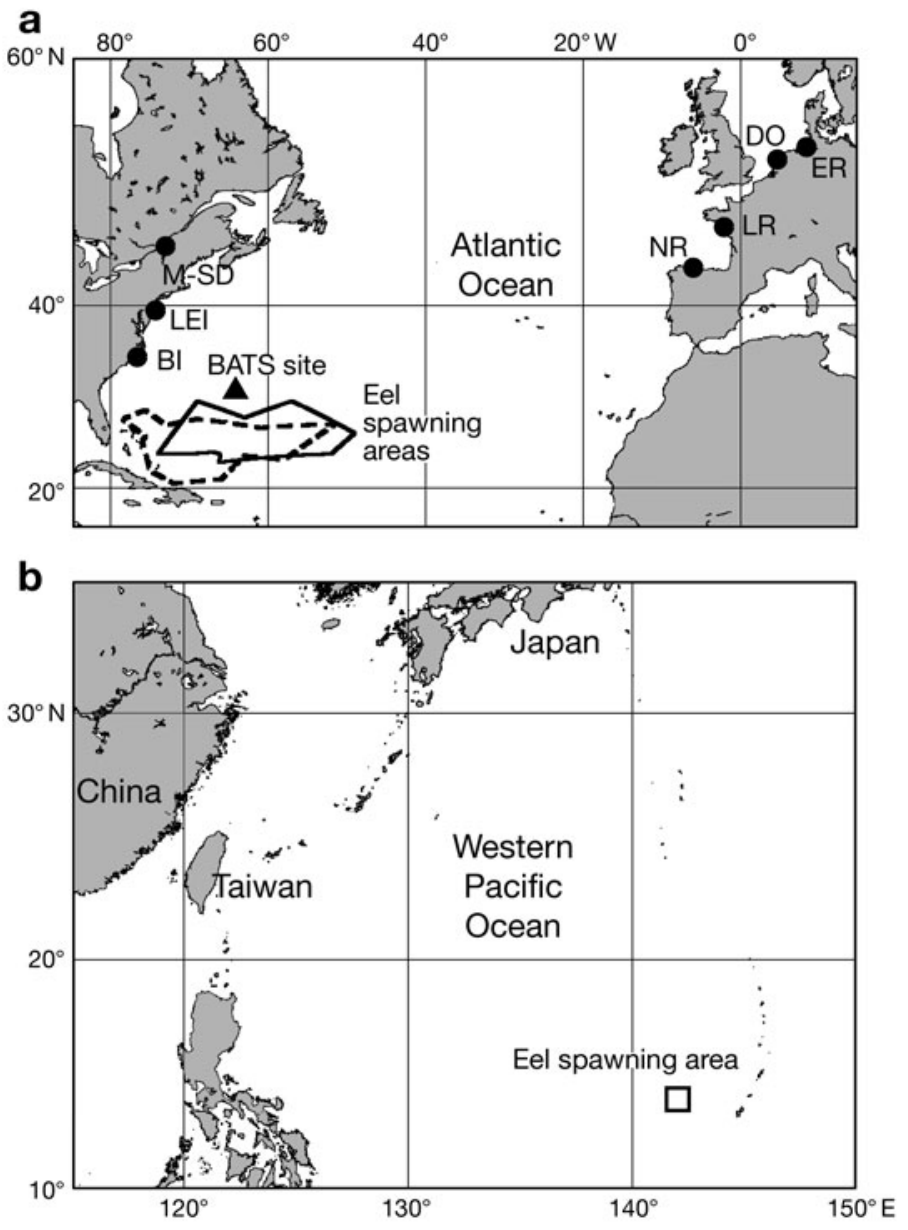

Fig. 1. (a) Location of American (-- -) and European (-) eel spawning areas (data from McCleave 1993). American eel recruitment sampling sites, LEI: Little Egg Inlet, BI: Beaufort Inlet, M-SD: Moses-Saunders Dam (Ontario). European eel recruitment sampling sites, ER: Ems River, DO: Den Oever, LR: Loire River, NR: Nalon River. ( $\boldsymbol{\Delta})$ Bermuda Atlantic Time-series Study (BATS) site. (b): Location of Japanese eel spawning area (square; data from Tsukamoto 2006)

sukawa 2003). Fishing has been proposed as the major factor impacting the European eel population (Dekker 2004). However, although fishing pressure on American glass eel was lower than that on European and Japanese eels before the 1980s, the population exhibited similar signs of declining trends at the same period (Casselman 2003). Notwithstanding stock-specific declining factors, the worldwide synchrony in the decline of eel abundances suggests that common factors such as ocean climate (ocean circulation, temperature or food availability) may have influenced eel population dynamics (Knights 2003, Friedland et al. 2007). As spawning, larval development, feeding, and migration take place in the open ocean, oceanic environmental conditions are believed to be of primary importance for the survival of eel larvae and, therefore, eel recruitment (Knights 2003, Friedland et al. 2007).
Significant negative correlations were found between the North Atlantic Oscillation (NAO) and the catch of glass eels at Den Oever in the Netherlands over the period 1938 to 2005 (Knights 2003, Friedland et al. 2007). Negative relationships have been found between Japanese eel recruitment and the El Niño Southern Oscillation (ENSO; Kimura et al. 2001, Sugimoto et al. 2001, Kim et al. 2007). However, such integrative indices do not allow the elucidation of the precise ecological processes involved, and a novel aspect of our work was to focus on trophic linkage as a key factor for recruitment. No quantitative studies have been carried out to investigate the link between food availability and survival of eel larvae, even though this has been suggested (Castonguay et al. 1994, Désaunay \& Guérault 1997).

The temperature of the northern hemisphere has increased more in the 20th century than in any other century during the last $1000 \mathrm{yr}$, with a main warming period from 1976 onward. The estimate from the Intergovernmental Panel on Climate Change (IPCC) is that the global average surface temperature has increased by $0.6^{\circ} \mathrm{C}$ over the last $100 \mathrm{yr}$ (IPCC 2007). This globalscale warming has resulted in increased oceanic temperatures and has strongly affected the spatial and temporal dynamics of a broad range of marine organisms (Beaugrand et al. 2002, Perry et al. 2005). Although responses of marine organisms to climate change have received increasing attention in recent years, the effects of increased sea surface temperature (SST) on the survival of fish larvae and subsequent recruitment, and the resulting impact on fisheries, remain poorly understood. Planktonic food limitation has long been considered to be the dominant factor leading to variability in survival and recruitment of fish larvae (Hjort 1914). Remote sensing observations of the open ocean have revealed that the recent SST increase has triggered large spatial changes in the vertical structure and, consequently, a reduction in the global production of oceanic phytoplankton (Behrenfeld et al. 2006). The increase in temperatures since the early $1980 \mathrm{~s}$ is also believed to have resulted in a $6 \%$ decrease in global primary production (PP), a decline that is mostly due to a pronounced decline in net PP at mid and low latitudes (Gregg et al. 2003), including eel spawning areas.

In the present study, we examined the relationships between the recruitment patterns of European, American, and Japanese eel and patterns of marine PP in their respective spawning areas. These 3 temperate species represent $90 \%$ of world eel catches over the 1950 to 2005 period (www.fao.org/fishery/topic/ 16073). We tested the hypothesis that recruitment of these eel species is determined by food availability during their early life stages (as leptocephali). 
Although the diet of eel larvae remains controversial, it has been suggested that they primarily feed on particulate and dissolved organic matter, i.e. at very low trophic levels (Otake et al. 1993, Mochioka \& Iwamizu 1996, Pfeiler 1999). Organic matter and PP are strongly correlated in the North Atlantic and North Pacific gyres (e.g. Bates 2001, DuRand et al. 2001, Pilskaln et al. 2005), and PP can therefore be used as a proxy of food availability for leptocephali. It has recently been established that a trophic link exists between marine PP in the Sargasso Sea and the recruitment of glass eels in European waters: variations in food availability for eel larvae in the spawning area are shown to be strongly positively correlated with fluctuations in recruitment success in subsequent years (Bonhommeau et al. 2008). In this study, we investigate whether this trophic linkage can generally be observed for European, American and Japanese eel populations. Using short- and long term time series and regime shift detection methods, we then analysed the effects of global warming on PP in eel spawning areas and subsequent impacts on eel recruitment.

\section{MATERIALS AND METHODS}

Eel recruitment data. For European eel, the recruitment series used for the short-term analysis was the original series from the Loire River over the period 1994 to 2004 selected by Bonhommeau et al. (2008), because it provides the best picture of year-to-year fluctuations. Data used for the long-term analysis were from the 4 longest time-series of glass eel recruitment available from the ICES Working Group on eel (ICES 2006), i.e. from the Ems River (Germany), Den Oever (Netherlands), Loire River (France), and Nalon River (Spain) (Fig. 1). To define a European glass eel recruitment index over the period 1960 to 2005, these time series were averaged after standardization (divided by their mean over the observation period).

American glass eel recruitment data used for shortterm analysis are from Sullivan et al. (2006), who studied 2 sampling sites, Little Egg Inlet (New Jersey) and Beaufort Inlet (North Carolina), over the period 1986 to 2004 (Fig. 1). Data used for the long-term analysis were from the index produced from daily passage at the Moses-Saunders dam eel ladder in the upper St. Lawrence River (Ontario, Canada) over the period 1974 to 2001. This index is fully described in Casselman (2003). This series was 4 yr lagged, since eels were caught an average of $4 \mathrm{yr}$ after the elver stage (Castonguay et al. 1994).

The Japanese recruitment index was the annual catch of glass eels in Japan from 1965 to 2001 and is described in Tatsukawa (2003).
Primary production data. To our knowledge, in situ data were only available from Atlantic eel spawning areas and not from the Japanese eel spawning area. We used data provided by the Bermuda Institute of Ocean Sciences (BIOS), which has been carrying out in situ sampling of PP during regular cruises since 1988 (Fig. 1). The Bermuda Atlantic Time-series Study (BATS) station is located in the west central Sargasso Sea and can, as a whole, be considered as a representative eel spawning area (Nelson et al. 2004). PP data, together with details of sampling and analytical methods used, are available on the BIOS website (http://bats.bios.edu/bats_form_prod.html). Different sampling events of leptocephali in this region revealed a preferred depth of $160 \mathrm{~m}$ during the day and $60 \mathrm{~m}$ at night (Schoth \& Tesch 1982 1984, Castonguay \& McCleave 1987). For this study, PP was integrated over a period of $6 \mathrm{mo}$, from January to July, to derive an average estimate of the annual productivity in the Sargasso Sea over the spawning period of Atlantic eels. Most of the PP occurs during this period of the year, and averaging over this period also helps to account for the integration time of PP in the first levels of the food chain. Moreover, the hatching periods between March and July for the European eel and between February and April for the American eel are included within these 6 mo (McCleave 1993, Wang \& Tzeng 2000).

Temperature data as a proxy for primary production. We used decadal changes in SST in eel spawning areas as a proxy for PP to investigate the impact of warming on recruitment success since the 1960s. Although long-term field measurements of PP are not specifically available for the Sargasso Sea or southwestern North Pacific, it has been shown that, in warm stratified surface waters over decadal time scales, increasing SSTs lead to a decrease in PP. A clearly identified process in this context is that a rise in SST reduces mixing of the upper part of the water column which, in turn, reduces the upward supply of nutrients (Behrenfeld et al. 2006). In particular, the increased SST in the western North Atlantic and North Pacific (especially at lower latitudes) has been shown to be negatively correlated with PP over decadal time scales (Sugimoto \& Tadokoro 1998, Miller \& Schneider 2000, Bates 2001, Limsakul et al. 2001, Nelson et al. 2004, Watanabe et al. 2005, Behrenfeld et al. 2006, Aita et al. 2007, Hashioka \& Yamanaka 2007). This complex response of PP to changes in SST probably arises because temperature not only affects biota directly - a $1^{\circ} \mathrm{C}$ increase in temperature is rarely lethal — but also acts as a proxy for other physical processes (i.e. inhibition of nutrient circulation due to enhanced stratification of the water column), thus regulating the size structure, taxonomic composition, and abundance of phytoplankton communities (Li 2002). 
The average annual SST during the eel spawning period in the Sargasso Sea (March to July) was computed using SST data from the BATS site over the period of 1960 to 2005 (http://bats.bios.edu/bats_form_ ctd.html; Fig. 1). Details on the computation of the Sargasso Sea SST are provided in Bonhommeau et al. (2008).

Data from the Japan Meteorological Agency (JMA) were used to estimate average annual SST in the Japanese eel spawning area for the 1966 to 2001 period. The mean annual SST was computed using $10 \mathrm{~d}$ mean SSTs that are available from 1950 until present on the JMA website (http://goos.kishou.go.jp/ rrtdb/usr/pub/JMA/wnpsst/). The $10 \mathrm{~d}$ mean SSTs were averaged first by month and then by year.

Statistical analyses. Relationships between environmental descriptors and eel recruitment indices was determined using 3 different time series analysis methods. Short-term relationships between PP and recruitment indices were analysed for the 2 Atlantic species (over $11 \mathrm{yr}$ for the European eel and $13 \mathrm{yr}$ for the American eel). Long-term relationships were studied between temperature in eel spawning areas and eel recruitment indices for all 3 species (over 46 yr for the European eel, $28 \mathrm{yr}$ for the American eel, and $36 \mathrm{yr}$ for the Japanese eel). Finally, regime shift detection was used to detect any synchrony between the years of transition in SST and eel recruitment indices for the 3 species.

Procedures for statistical testing of the degree of correlation between the recruitment and environmental series must account for autocorrelation in the time series, because this may result in an artificial increase in the statistical significance of the correlation test. We used methods specifically designed to study long-term and short-term correlations in the case of auto-correlated time series (Pyper \& Peterman 1998).

Time lags were included to account for the duration of eel larval migration and to link environmental descriptors to glass eel recruitment. Friedland et al. (2007) used a 1 yr lag, but Knights (2003) and Bonhommeau et al. (2008) used a delay of 2.5 to 3 yr. These discrepancies arise from the use of different methods for the estimation of migration duration, which are discussed below. In this study, we tested different time lags (1 to $3 \mathrm{yr}$ for the European and American eel, 0 to 1 yr for the Japanese eel).

Testing short-term correlations. To assess correlations between interannual variations of PP and recruitment indices, both of the initial length $N$, we removed autocorrelation by 'prewhitening' the data series, i.e. by first-order differencing prior to statistical testing (Thompson \& Page 1989, Pyper \& Peterman 1998). The aim is to transform the original data to eliminate autocorrelation whilst retaining the high-frequency signal
(Fox et al. 2000). After the transformation, standard correlation tests can be applied to the resultant series. Pearson coefficients were used to assess the linear relationship between the first-order differenced recruitment and environmental time series, and to test correlations. The p-value was assessed by comparing the Pearson coefficient against its theoretical Student distribution with $(N-1)-2$ degrees of freedom (df) where $(N-1)$ is the length of the first-differenced time series. We estimated the different correlations between glass eel recruitment indices and environmental descriptors using different lags to take into account the different assumed migration duration. We checked that autocorrelation was correctly removed using the autocorrelation function (ACF).

Testing long-term correlations. To analyse longterm patterns between recruitment indices and SST time series, we first smoothed the data with a $5 \mathrm{yr}$ moving average to analyse low-frequency sources of covariation (Pyper \& Peterman 1998). The Pearson coefficient was used to test correlations between the smoothed time series. To compensate for autocorrelation in the smoothed time series of the length $N$, the df of the Student significance test, denoted $N^{*}-2$, was adjusted following the equation proposed by Chelton (1984) and modified by Pyper \& Peterman (1998):

$$
\frac{1}{N^{*}} \approx \frac{1}{N}+\frac{2}{N} \sum_{j} r_{x x}(j) \times r_{y y}(j)
$$

where $N^{*}$ is the corrected sample size interpreted as the number of independent joint observations on the 2 time series $x$ (recruitment data) and $y$ (SST data), $N$ is the length of the initial time series, and $r_{X X}(j)$, and $r_{Y Y}(j)$ are the autocorrelation of $x$ and $y$ at $\operatorname{lag} j$. Estimators of autocorrelation $r$ are obtained using the Box-Jenkins equation (Box \& Jenkins 1976), modified by Chatfield (1989):

$$
r_{X X}(j)=\frac{N}{N-j} \frac{\sum_{j=1}^{N-j}\left(X_{t}-\bar{X}\right)\left(X_{t-j}-\bar{X}\right)}{\sum_{j=1}^{N}\left(X_{t}-\bar{X}\right)}
$$

where $\bar{X}$ is the overall mean.

Pyper \& Peterman (1998) tested a variety of df adjustment methods and found Eq. (1) to be robust and unbiased compared to other methods. This method is also robust to the number of lags applied in the dfreduction (Eq. 1). In the present analysis, we computed autocorrelations until the 9th lag approximately equalled N/5 (Pyper \& Peterman 1998).

Regime shift detection. Detection of major changes in glass eel recruitment indices and SST was performed using a sequential regime shift detection (Rodionov \& Overland 2005). This method allows estimating the magnitude of the shift by calculating a regime shift index (RSI). The significance level (p) is the level at 
which the null hypothesis that the mean values of the 2 regimes are equal is rejected by the 2-tailed Student's $t$-test. The cut-off time scale ( 1 ) determines the minimum duration of a regime. The key concept is that there must be significant shifts in mean value relative to the within-regime variance in order to detect a new regime. In the present analysis, the cut-off length (1) was set to $10 \mathrm{yr}$ and the probability level at $\mathrm{p}=0.01$. We also tested the sensitivity of the results to the parameters by setting 1 to 15 and $20 \mathrm{yr}$ and p to equal 0.05 .

\section{RESULTS}

\section{Short-term relationships between $\mathrm{PP}$ and recruitment indices}

We analysed the relationship between PP in eel spawning areas and recruitment of European and American eels over 11 and 13 yr, respectively. For the European and the American eel, only a 2.5 and $1.5 \mathrm{yr}$ lag, respectively, exhibited a significant correlation. Highly significant positive correlations were found between PP and recruitment for European (Pearson's $\mathrm{r}=$ 0.74, $\mathrm{p}=0.015$ ) and American eel (Pearson's $\mathrm{r}=0.71$, $\mathrm{p}=0.010$ ) (Fig. 2). Thus, more than $50 \%$ of the variation in coastal glass eel recruitment success can be explained by fluctuations in PP in the eel spawning area. The tight link between Sargasso Sea PP and subsequent recruitment of European and American eels suggests that food availability in the Sargasso Sea exerts a major control on eel larval survival, and that such bottom-up control has been driving the recruitment of European and American eels for more than a decade.

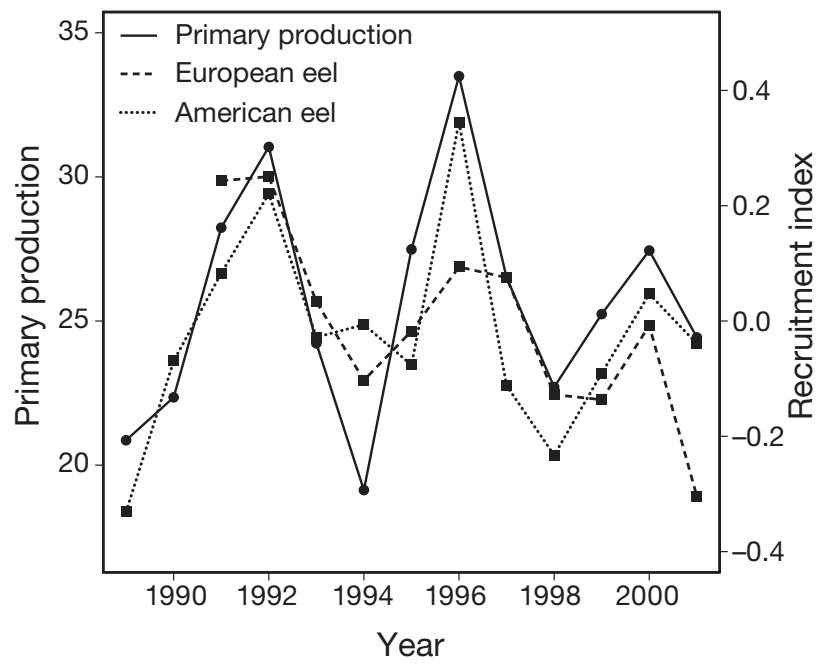

Fig. 2. Short-term time series of European and American eel recruitment indices (no unit), lagged by 1.5 and $2.5 \mathrm{yr}$, respectively, and integrated primary production $\left(\mathrm{mgC} \mathrm{m}^{-3} \mathrm{~d}^{-1}\right)$ at the Bermuda Atlantic Time-series Series (BATS) site

\section{Long-term relationships between fluctuations in SST and eel recruitment indices}

Fluctuations in Sargasso Sea SSTs followed the same trends as the Northern Hemisphere Temperature (NHT) anomaly, suggesting a direct link between global warming and the increase in SST in these areas (Fig. 3).

Over the past $40 \mathrm{yr}$, the long-term correlations between Sargasso Sea SST and recruitment indices of Atlantic eel species were the most significant using a $2.5 \mathrm{yr}$ lag for the European eel $(\mathrm{r}=-0.88, \mathrm{p}=0.03$, Fig. 4a) and a $1.5 \mathrm{yr}$ lag for the American eel $(\mathrm{r}=-0.90$, $\mathrm{p}=0.03$, Fig. $4 \mathrm{~b}$ ). The correlation between SST in the Japanese eel spawning area and the Japanese eel recruitment index were most significant using a $0.5 \mathrm{yr}$ $\operatorname{lag}(\mathrm{r}=-0.84, \mathrm{p}=0.01$, Fig. $4 \mathrm{c})$. The decrease in glass eel recruitment appears to be strongly inversely correlated with warming in eel spawning areas.

\section{Regime shifts in eel recruitment indices, SST and NHT}

The regime shift detection method applied to raw time series of recruitment and temperature revealed a negative regime shift in 1982 for the European eel and in 1981 for the American eel, while a positive regime shift in Sargasso Sea SST was shown for 1979 (Fig. 3 \& 5). A negative regime shift was detected for Japanese

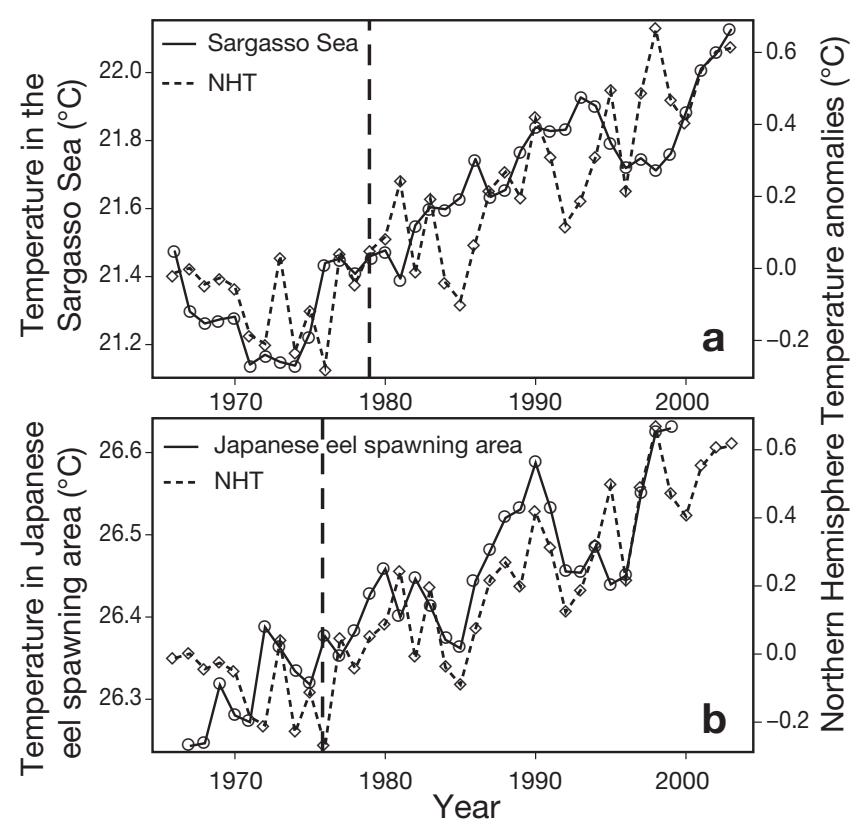

Fig. 3. Sea surface temperature (SST, ${ }^{\circ} \mathrm{C}$, solid line) in (a) the Sargasso Sea and (b) the spawning area of the Japanese eel, versus Northern Hemisphere Temperature (NHT) anomalies $\left({ }^{\circ} \mathrm{C}\right.$, available at www.cru.uea.ac.uk/cru/data/temperature; dashed line). Vertical dashed lines represent the regime shift in temperature found using the regime shift detection method 

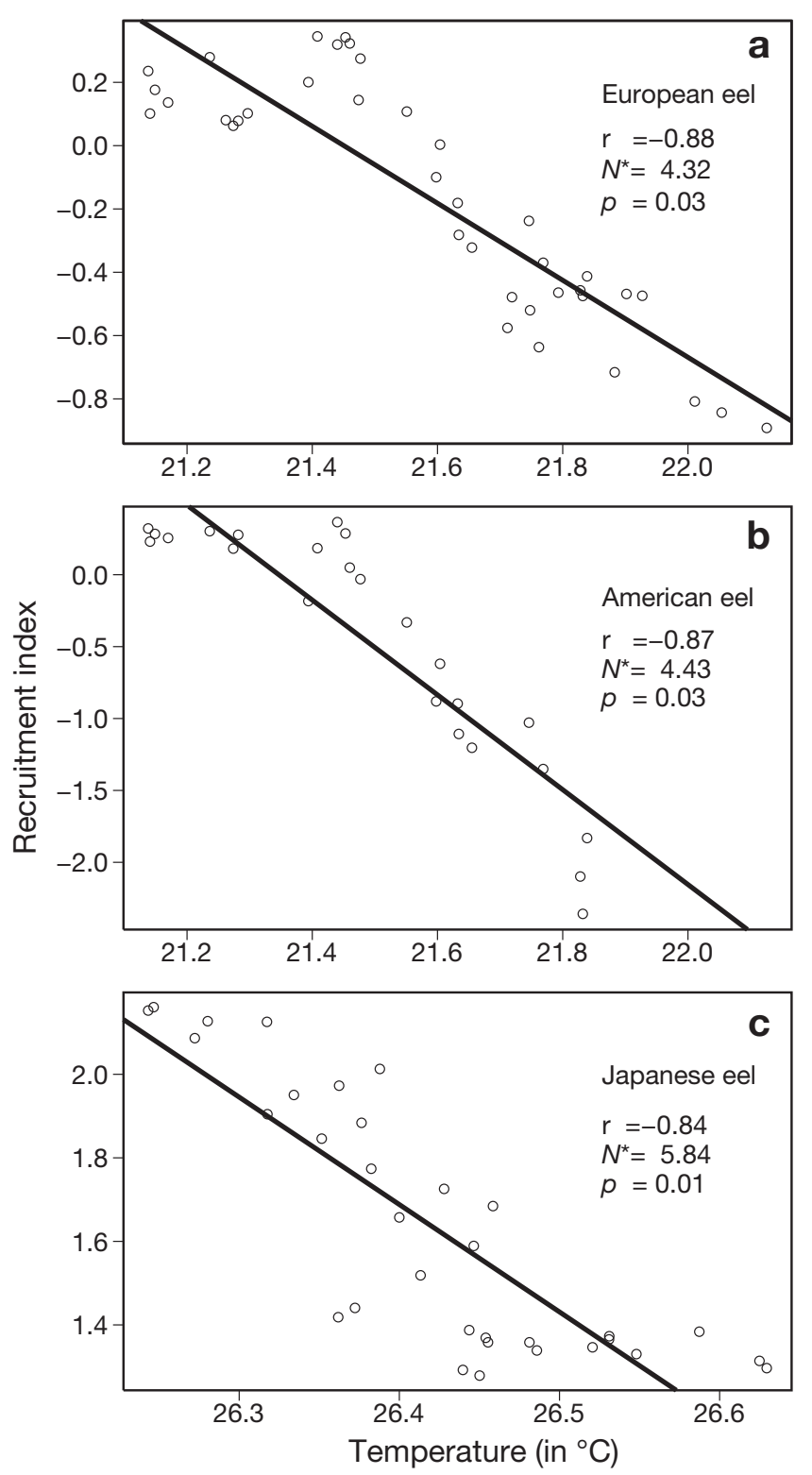

Fig. 4. Long-term relationships (5 yr moving averages) between sea surface temperature $\left(\mathrm{SST}^{\circ}{ }^{\circ} \mathrm{C}\right)$ in the eel spawning areas and glass eel recruitment indices for (a) European, (b) American, and (c) Japanese eels, lagged by 2.5, 1.5, and $0.5 \mathrm{yr}$, respectively, to account for different migration durations. r: correlation coefficient, $N^{*}$ : degrees of freedom after compensating for serial autocorrelation, $p$ : $\mathrm{p}$-value with $N^{*}-2$ degrees of freedom

eel recruitment in 1977, 1 yr after the shift in temperature in the Pacific Ocean detected by Hare \& Mantua 2000. For each eel species, the negative shift in recruitment followed a positive shift in temperature (Fig. 5). In each case, time lags between temperature and recruitment shifts corresponded to lags found previously. These findings reinforce the idea of a strong link between temperature and recruitment.

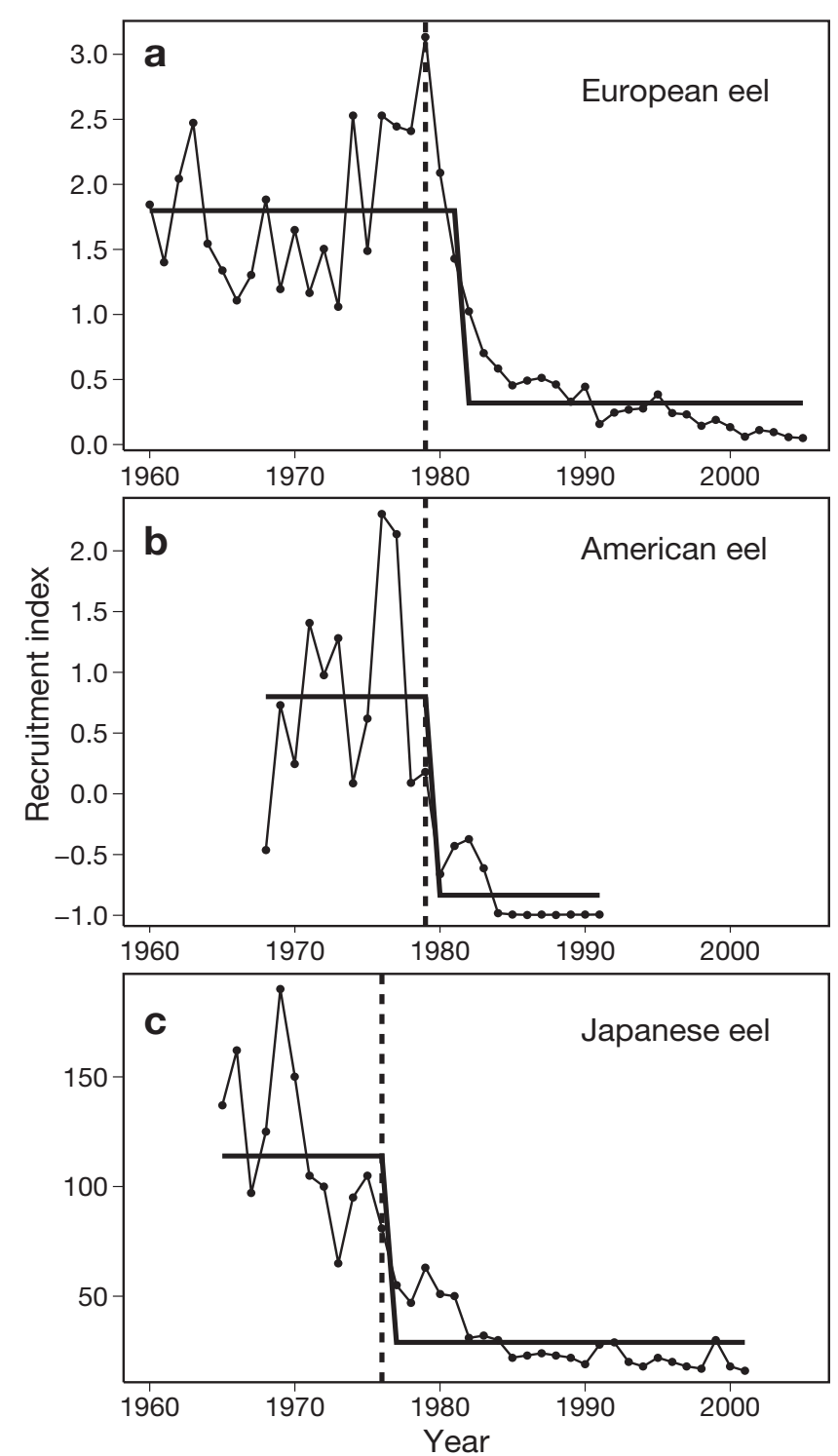

Fig. 5. Time series of (a) European, (b) American, and (c) Japanese eel recruitment indices $(\rightarrow-$, no unit). - : regime shift detection, - - -: main regime shifts in sea surface temperature (SST) in the North Atlantic (in 1979) and North Pacific (in 1977) oceans

\section{DISCUSSION}

Primary production as a proxy for eel larval food availability and importance during earliest life stages

This study used PP as an indicator of eel larval food supply. This is justified by general considerations (Ware \& Thomson 2005) and based on the available knowledge about leptocephalus diet. Two potential sources of nutrition have been proposed for eel larvae: dissolved organic matter (DOM) and particulate organic matter (POM) in the form of zooplankton fecal pellets and larvacean houses (Otake et al. 1993, Mochioka \& Iwamizu 
1996, Pfeiler 1999). Marine snow has also been proposed as a potential source of nutrition (Knights 2003). Since a strong linear relationship between phytoplankton and POM has been described in the Sargasso Sea (DuRand et al. 2001), PP has been considered to be a good proxy for leptocephali food (Bardonnet \& Riera 2005). Biological production may directly impact eel larvae because of its characteristics. Eel larvae are qualified as type II larvae based upon their unique developmental strategy. Following a post-hatch period in which the yolk-sac is absorbed, the larval fish show a dramatic increase in size during which up to $40 \%$ of the leptocephalus maximum length is attained while only 5 to $7 \%$ of the maximum mass is accumulated (Bishop \& Torres 2001). This unique strategy allows them to increase rapidly in size while devoting the majority of their energy to metabolism, i.e. nutrition and locomotion, and not to increase in body mass as most other larval fish. Food availability seems critical during early life stages to determine the capacity of eel larvae to rapidly reach a size that allows them to drift into currents.

The specific location of Japanese eel spawning areas near seamounts may be linked to the functional role of these places in nutrient transport. Seamounts have been shown to induce perturbations in nutrient distributions, leading to enhanced upward transport of nutrients into the euphotic zone (Furuya et al. 1995). This process results in an elevated amount of chl a downstream of the seamount. Consequently, seamount ecosystems may be adequate areas to provide eel larvae with a sufficient food supply. The assumed location of these areas relative to frontal systems (e.g. McCleave et al. 1987, Kleckner \& McCleave 1988, Kimura et al. 2001) also implies that mixing processes encourage deepening of the mixed depth layers and nutrient circulation.

Food availability in spawning areas seems therefore to be an important factor for eel larval survival during the post-hatch period of these 3 eel species and explains the relationships found between PP and glass eel recruitment. The importance of food availability during the oceanic migration has previously been demonstrated (Désaunay \& Guérault 1997, Kettle \& Haines 2006).

\section{Global warming effect on eel recruitment}

The fluctuations of SST in eel spawning areas are consistent with changes observed for the northern hemisphere temperature. Changes in SST of similar orders of magnitude have been found in other studies dealing with large-scale changes in SST and its impact on marine ecosystems (e.g. Donner et al. 2007, Thresher et al. 2007). Based on our analyses, we did not detect a change or trend in the intra-annual temperature variability over the 4 last decades.
The change in SST has been estimated to lie between 0.4 and $0.8^{\circ} \mathrm{C}$ (Fig. 3). We hypothesized that an increase in SST has an indirect effect through reinforcement of the vertical thermal stratification of the water column, leading to a decrease in marine production in warm eel spawning areas (Sugimoto \& Tadokoro 1998, Bates 2001, Richardson \& Schoeman 2004, Watanabe et al. 2005, Behrenfeld et al. 2006). This is strongly supported by the highly positive correlation found between PP and glass eel recruitment, lagged to account for migration duration (i.e. $2.5 \mathrm{yr}$ for the European eel, $1.5 \mathrm{yr}$ for the American eel, and $0.5 \mathrm{yr}$ for the Japanese eel). Global change is known to affect the abundance as well as the size of marine plankton. For instance, Beaugrand et al. (2003) showed that an increasing temperature in the North Sea has led to a decrease by a factor of 2 in the mean size of calanoid copepods after the 1980 s, which in turn led to a decrease in cod recruitment. However, the current lack of accurate information on the diet of eel larvae impedes the analysis of such a relationship. The patterns of eel recruitment observed in the present study could be part of longer-term cycles, but the historical data used are not fully reliable. However, the change in abundance detected in the present analysis suggests an abrupt regime shift, rather than a long-term cycle.

The increase in temperature can be relatively small locally. However, when integrated over the whole period of migration, a subtle increase in temperature may have dramatic effects on eel larvae, for instance via the reduction in nutrient supply. It would be interesting to analyse the impact of the food availability along the whole migration routes of leptocephali on eel larva survival. However, the migration duration is not sufficiently well-known to perform such analyses.

To analyse the relationships between eel recruitment and environmental conditions, we tested several lags. For the 3 distinct analyses (short-term relationships of recruitment to PP of Atlantic species, longterm links of recruitment of all 3 eel species to SST, and delays between regime shifts), the most significant correlations were obtained with similar time lags: $2.5 \mathrm{yr}$ for the European eel, $1.5 \mathrm{yr}$ for the American eel and $0.5 \mathrm{yr}$ for the Japanese eel. The $0.5 \mathrm{yr}$ delay used for the Japanese eel is consistent with current available knowledge about its migration duration (Cheng \& Tzeng 1996, Kimura et al. 1999). Wang \& Tzeng (2000) and Shinoda (2004) also showed that migration of Japanese eel takes between 98 and 227 d.

Migration durations of Atlantic eels remain controversial: ages at recruitment back-calculated by otolith microstructure analysis ranged from 7 to 15 mo (Lecomte-Finiger 1994, Cheng \& Tzeng 1996, Arai et al. 2000), but studies based on daily growth increments in glass eel otoliths have been criticized (McCleave et 
al. 1998, Svedäng et al. 1998, Cieri \& McCleave 2000). There is likely a period during metamorphosis when the oceanic eel larvae do not deposit daily rings because of a low metabolic rate. It is also noteworthy that there may be some resorption of otolith chemicals during metamorphosis (Antunes \& Tesch 1997). In addition, according to McCleave et al. (1998), European eel leptocephali are unable to swim across the Atlantic Ocean in less than 1 to 2 yr. The ocean circulation model by Kettle \& Haines (2006) indicates a migration duration of 2.5 to 3 yr for European eel larvae. Our results appear to contradict approaches based on otolith microstructure analysis, but fit with estimates based on larval drift.

\section{Other factors associated with ocean climate change}

The relationships between the Transport index (i.e. the strength of the Gulf Stream; Curry \& McCartney 2001), the Gulf Stream Index (i.e. the latitude of the Gulf Stream; Taylor \& Stephens 1998) and European glass eel recruitment have not been clearly established (Bonhommeau et al. 2008). However, other studies suggest that leptocephali may be affected by oceanic features because of their long oceanic larval phase (Knights 2003). Recent analysis by Friedland et al. (2007) suggested that the influence of ocean parameters, such as the shallowing of the mixed layer depth inducing a decrease in $\mathrm{PP}$, the drift conditions in the larval transport area, and declining trends in winds have contributed to declining recruitment as well. Friedland et al. (2007) used the Den Oever Index, which is based on regular scientific sampling carried out at Den Oever behind the sluices of a dam at $2 \mathrm{~h}$ intervals at night during spring, using a $1 \mathrm{~m}^{2}$ dipnet in close proximity to one of the closed sluices. They showed that fluctuations of the Den Oever Index are related to fluctuations in the North Atlantic Oscillation (NAO), which indicates that eel recruitment may be influenced by the physical and biological structure of the North Atlantic. It has been suggested that the changes associated with these types of atmospheric forcing could alter the biological characteristics of the surface layer where leptocephali feed (M. Miller et al. unpubl. data). Friedland et al. (2007) also suggested that fluctuations in latitude of the $22.5^{\circ} \mathrm{C}$ isotherm, which is a useful indicator of the northern limit of the European eel spawning area, may affect both spawning location and transport of the leptocephali out of the Sargasso Sea by increasing retention within the Sargasso Sea gyre. Moreover, the possibility of leaving the Sargasso Sea may be altered by changes in winds in the northern Sargasso Sea, which have reduced southward Ekman transports and hence contributed to increase lar- val retention in the Sargasso Sea gyre. Such changes in larval retention might add up to the bottom-up control process suggested by our result, and underline the various and potential combined effects of environmental changes on recruitment of European eel.

Similarly, Kimura et al. (2001) showed a certain synchrony between Anguilla japonica recruitment and salinity fronts driven by ENSO in the Japanese eel spawning area. If eel eggs hatch south of the salinity front, larvae may be carried away by the southward Mindanao current. By contrast, hatching north of the front, leptocephali may follow the Kuroshio current, which transports them from Taiwan to Japan (Kimura et al. 1999). During the El Niño event in 2002, Kimura \& Tsukamoto (2006) noticed that small larvae $(<10 \mathrm{~mm}$ total length) were collected just south of the salinity front where these young larvae had never been found in normal years. Kim et al. (2007) also demonstrated that the changing oceanic conditions associated with climate change have resulted in decreased recruitment of Japanese eel.

Trophic conditions in eel spawning areas appear to affect the success of eel recruitment several years later and thousands of kilometres away from the spawning site. Decadal changes in SST have occurred around the Mariana Islands and in the Sargasso Sea; abrupt transitions in the temperature regimes of these regions have occurred in the late 1970 s, followed by a period of persistent warming (Hare \& Mantua 2000, Bonhommeau et al. 2008). These conditions seem to have induced changes in eel larval survival through bottomup trophic regulation. The relationships between PP and glass eel recruitment indices in the North Atlantic and North Pacific were found at different nested time scales, i.e. short-term for interannual fluctuations, medium-term for regime shifts and long-term for decadal trends. These consistent and synchronous results at multiple temporal scales provide a general explanatory mechanism for how climate-driven changes in oceanic plankton production can affect eel recruitment in the Atlantic and Pacific Oceans. The destabilization of fish populations due to overfishing leads to higher variability of abundances, associated with higher sensitivity to the environment (Anderson et al. 2008, Stenseth \& Rouyer 2008). The multiple anthropogenic effects affecting eel, such as overfishing, may therefore have destabilized eel populations and increased their sensitivity to environmental conditions. We therefore argue that, in conjunction with anthropogenic factors such as overfishing and habitat loss and degradation, global climate variations have resulted in a major bottom-up control contributing to the current decline of eel stocks. Such a combination of negative processes calls for a strict precautionary approach regarding future fisheries management plans. 
Acknowledgements. The authors thank M. Castonguay, B. Knights, A. Bardonnet, D. Gascuel, L. Devine, A. Caskenette, D. Duplisea, J. Guitton, L. Pecquerie and P. Lenne for their comments and help. We appreciate the comments of 2 anonymous reviewers that have improved the manuscript.

\section{LITERATURE CITED}

Aita MN, Yamanaka Y, Kishi MJ (2007) Interdecadal variation of the lower trophic ecosystem in the northern Pacific between 1948 and 2002, in a 3-D implementation of the NEMURO model. Ecol Modell 202:81-94

Anderson CNK, Hsieh CH, Sandin SA, Hewitt R and others (2008) Why fishing magnifies fluctuations in fish abundance. Nature 452:835-840

Anonymous (2003) Worldwide decline of eel resources necessitates immediate action - Québec declaration of concern. Fisheries 28:28-30

Antunes C, Tesch FW (1997) A critical consideration of the metamorphosis zone when identifying daily rings in otoliths of European eel, Anguilla anguilla (L). Mar Biol 6: 102-107

> Arai T, Otake T, Tsukamoto K (2000) Timing of metamorphosis and larval segregation of the Atlantic eels Anguilla rostrata and $A$. anguilla, as revealed by otolith microstructure and microchemistry. Mar Biol 137:39-45

Bardonnet A, Riera P (2005) Feeding of glass eels (Anguilla anguilla) in the course of their estuarine migration: new insights from stable isotope analysis. Estuar Coast Shelf Sci 63:201-209

Bates NR (2001) Interannual variability of oceanic $\mathrm{CO}_{2}$ and biogeochemical properties in the western North Atlantic subtropical gyre. Deep-Sea Res II 48:1507-1528

Beaugrand G, Reid PC, Ibanez F, Lindley JA, Edwards M (2002) Reorganization of North Atlantic marine copepod biodiversity and climate. Science 296:1692-1694

Beaugrand G, Brander K, Lindley J, Souissi S, Reid P (2003) Plankton effect on cod recruitment in the North Sea. Nature 426:661-664

Behrenfeld MJ, O'Malley RT, Siegel DA, McClain CR and others (2006) Climate-driven trends in contemporary ocean productivity. Nature 444:752-755

Bishop RE, Torres JJ (2001) Leptocephalus energetics: assembly of the energetics equation. Mar Biol 138:1093-1098

Bonhommeau S, Chassot E, Rivot E (2008) Fluctuation in European eel (Anguilla anguilla) recruitment resulting from environmental changes in the Sargasso Sea. Fish Oceanogr 17:32-44

Box GEP, Jenkins GW (1976) Time series analysis: forcasting and control. Holden-Day, San Francisco, CA

Casselman JM (2003) Dynamics of resources of the American eel, Anguilla rostrata: Declining abundance in the 1990s. In: Aida K, Tsukamoto K, Yamauchi K (eds) Eel biology. Springer-Verlag, Tokyo, p 255-274.

Castonguay M, McCleave JD (1987) Vertical districutions, diel and ontogenic vertical migrations and net avoidance of leptocephali of Anguilla and other common species in the Sargasso Sea. J Plankton Res 9:195-214

Castonguay M, Hodson PV, Moriarty C, Drinkwater KF, Jessop BM (1994) Is there a role of ocean environment in American and European eel decline? Fish Oceanogr 3: 197-203

Chatfield C (1989) The analysis of time series: an introduction. Chapman and Hall, London

Chelton DB (1984) Short-term climatic variability in the Northeast Pacific Ocean. In: Pearcy WG (ed) The influence of ocean conditions on the production of salmonids in the
North Pacific. Oregon State University Press, Corvallis, OR, p 87-99.

Cheng PW, Tzeng WN (1996) Timing of metamorphosis and estuarine arrival across the dispersal range of the Japanese eel Anguilla japonica. Mar Ecol Prog Ser 131:87-96

> Cieri MD, McCleave JD (2000) Discrepancies between otoliths of larvae and juveniles of the American eel: is something fishy happening at metamorphosis? J Fish Biol 57:1189-1198

Curry RG, McCartney MS (2001) Ocean gyre circulation changes associated with the North Atlantic Oscillation. J Phys Oceanogr 31:3374-3400

Dekker W (2003) Did lack of spawners cause the collapse of the European eel, Anguilla anguilla? Fish Manag Ecol 10: 365-376

Dekker W (2004) What caused the decline of the Lake IJsselmeer eel stock after 1960? ICES J Mar Sci 61:394-404

> Désaunay Y, Guérault D (1997) Seasonal and long-term changes in biometrics of eel larvae: a possible relationship between recruitment variation and North Atlantic ecosystem productivity. J Fish Biol 51:317-339

> Donner SD, Knutson TR, Oppenheimer M (2007) Modelbased assessment of the role of human-induced climate change in the 2005 Caribbean coral bleaching event. Proc Natl Acad Sci USA 104:5483-5488

DuRand MD, Olson RJ, Chisholm SW (2001) Phytoplankton population dynamics at the Bermuda Atlantic Timeseries station in the Sargasso Sea. Deep-Sea Res II 48: 1983-2003

> Feunteun E (2002) Management and restoration of European eel population (Anguilla anguilla): An impossible bargain. Ecol Eng 18:575-591

> Fox CJ, Planque BP, Darby CD (2000) Synchrony in the recruitment time-series of plaice (Pleuronectes platessa L) around the United Kingdom and the influence of sea temperature. J Sea Res 44:159-168

Friedland KD, Miller MJ, Knights B (2007) Oceanic changes in the Sargasso Sea and declines in recruitment of the European eel. ICES J Mar Sci 64:519-530

Furuya K, Odate T, Tagushi K (1995) Effects of a seamount on phytoplankton production in the western Pacific Ocean. In: Sakai H, Nozaki Y (eds) Biogeochemical processes and ocean flux in the Western Pacific. Terra Scientific Publishing Company, Tokyo, p 255-273.

> Gregg WW, Conkright ME, Ginoux P, O'Reilly JE, Casey NW (2003) Ocean primary production and climate: Global decadal changes. Geophys Res Lett 30:1809

> Hare SH, Mantua NJ (2000) Empirical evidence for North Pacific regime shifts in 1977 and 1989. Prog Oceanogr 47: 103-145

Hashioka T, Yamanaka Y (2007) Ecosystem change in the western North Pacific associated with global warming using 3D-NEMURO. Ecol Modell 202:95-104

Hjort J (1914) Fluctuations in the great fisheries of Northern Europe. Rapp PV Cons Int Explor Mer 20:1-228

ICES (International Council for the Exploration of the Sea) (2006) Reports of the Eifac/ICES working group on eels, Rome, Italy. ICES CM 2006/ACFM: 16, Ref. DFC, LRC, RMC. ICES, Copenhagen

IPCC (Intergovernmental Panel on Climate Change) (2007) Climate change 2007 - The physical science basis. Contribution of working group I to the fourth assessment report of the IPCC, Solomon S, Quin D, Manning M, Marquis M, Averyt K, Tignor MMB, Miller HL, Chen Z (eds) Cambridge University Press, Cambridge

Kettle AJ, Haines K (2006) How does the European eel (Anguilla anguilla) retain its population structure during 
its larval migration across the North Atlantic Ocean? Can J Fish Aquat Sci 63:90-106

Kim H, Kimura S, Shinoda A, Kitagawa T, Sasai Y, Sasaki H (2007) Effect of El Nino on migration and larval transport of the Japanese eel (Anguilla japonica). ICES J Mar Sci 64: 1387-1395

Kimura S, Tsukamoto K (2006) The salinity front in the North Equatorial Current: A landmark for the spawning migration of the Japanese eel (Anguilla japonica) related to the stock recruitment. Deep-Sea Res II 53:315-325

Kimura S, Doos K, Coward AC (1999) Numerical simulation to resolve the issue of downstream migration of the Japanese eel. Mar Ecol Prog Ser 186:303-306

Kimura S, Inoue T, Sugimoto T (2001) Fluctuation in the distribution of low-salinity water in the North Equatorial Current and its effect on the larval transport of the Japanese eel. Fish Oceanogr 10:51-60

Kleckner RC, McCleave JD (1988) The northern limit of spawning by Atlantic eels (Anguilla spp.) in the Sargasso Sea in relation to thermal fronts and surface water masses. J Mar Res 46:647-667

Knights B (2003) A review of the possible impacts of longterm oceanic and climate changes and fishing mortality on recruitment of anguillid eels of the Northern Hemisphere. Sci Total Environ 310:237-244

Lecomte-Finiger R (1994) The early-life of the European eel. Nature 370:424

Li WKW (2002) Macroecological patterns of phytoplankton in the northwestern North Atlantic Ocean. Nature 419: $154-157$

Limsakul A, Saino T, Midorikawa T, Goes JI (2001) Temporal variations in lower trophic level biological environments in the northwestern North Pacific Subtropical Gyre from 1950 to 1997. Prog Oceanogr 49:129-149

McCleave JD (1993) Physical and behavioral controls on the oceanic distribution and migration of leptocephali. J Fish Biol 43:243-273

McCleave JD (2001) Simulation of the impact of dams and fishing weirs on reproductive potential of silver-phase American eels in the Kennebec River basin, Maine. N Am J Fish Manag 21:592-605.

McCleave JD, Kleckner R, Castonguay M (1987) Reproductive sympatry of American and European eels and implications for migration and taxonomy. Am Fish Soc Symp 1: 286-297

McCleave JD, Brickley PJ, O'Brien KM, Kistner DA, Wong MW, Gallagher M, Watson SM (1998) Do leptocephali of the European eel swim to reach continental waters? Status of the question. J Mar Biol Assoc UK 78:285-306

Miller AJ, Schneider N (2000) Interdecadal climate regime dynamics in the North Pacific Ocean: theories, observations and ecosystem impacts. Prog Oceanogr 47:355-379

Mochioka N, Iwamizu M (1996) Diet of anguilloid larvae: Leptocephali feed selectively on larvacean houses and fecal pellets. Mar Biol 125:447-452

Nelson NB, Siegel DA, Yoder JA (2004) The spring bloom in the northwestern Sargasso Sea: spatial extent and relationship with winter mixing. Deep-Sea Res II 51:987-1000

Otake T, Nogami K, Maruyama K (1993) Dissolved and particulate organic matter as possible food sources for eel leptocephali. Mar Ecol Prog Ser 92:27-34

Perry AL, Low PJ, Ellis JR, Reynolds JD (2005) Climate change and distribution shifts in marine fishes. Science 308:1912-1915

Pfeiler E (1999) Developmental physiology of elopomorph leptocephali. Comp Biochem Physiol A 123:113-128

Pilskaln CH, Villareal TA, Dennett M, Darkangelo-Wood C,
Meadows G (2005) High concentrations of marine snow and diatom algal mats in the North Pacific Subtropical Gyre: Implications for carbon and nitrogen cycles in the oligotrophic ocean. Deep-Sea Res I 52:2315-2332

> Pyper BJ, Peterman RM (1998) Comparison of methods to account for autocorrelation in correlation analyses of fish data. Can J Fish Aquat Sci 55:2127-2140

Richardson AJ, Schoeman DS (2004) Climate impact on plankton ecosystems in the Northeast Atlantic. Science 305:1609-1612

> Rodionov S, Overland JE (2005) Application of a sequential regime shift detection method to the Bering Sea ecosystem. ICES J Mar Sci 62:328-332

Schmidt J (1923) Breeding places and migrations of the eel. Nature 111:51-54

> Schoth M, Tesch FW (1982) Spatial distribution of the 0-group eel larvae (Anguilla spec.) caught in the Sargasso Sea in 1979. Helgol Meersunters 35:309-320

Schoth M, Tesch FW (1984) The vertical distribution of small 0-group Anguilla larvae in the Sargasso Sea with reference to other anguilliform leptocephali. Kieler Meeresforsch 30:188-195

Shinoda A (2004) The ecology of inshore migration of the Japanese eel, Anguilla japonica. In Japanese with English summary. PhD thesis, University of Tokyo

Stenseth NC, Rouyer T (2008) Destabilized fish stocks. Nature 452:825-826

Sugimoto T, Tadokoro K (1998) Interdecadal variations of plankton biomass and physical environment in the North Pacific. Fish Oceanogr 7:289-299

Sugimoto T, Kimura S, Tadokoro K (2001) Impact of El Nino events and climate regime shift on living resources in the western North Pacific. Prog Oceanogr 49:113-127

Sullivan MC, Able KW, Hare JA, Walsh HJ (2006) Anguilla rostrata glass eel ingress into two, US east coast estuaries: patterns, processes and implications for adult abundance. J Fish Biol 69:1081-1101

Svedäng H, Wickström H, Reizenstein M, Holmgren K, Florenius $P$ (1998) Accuracy and precision in eel age estimation, using otoliths of known and unknown age. J Fish Biol 53: $456-464$

Tatsukawa K (2003) Eel resources in Asia. In: Aida K, Tsukamoto K, Yamauchi K (eds) Eel biology. SpringerVerlag, Tokyo, p 255-274.

> Taylor AH, Stephens JA (1998) The North Atlantic oscillation and the latitude of the Gulf Stream. Tellus A 50:134-142

Tesch FW (2003) The eel. Blackwell Publishing, Oxford

> Thompson KR, Page FH (1989) Detecting synchrony of recruitment using short, autocorrelated time series. Can J Fish Aquat Sci 46:1831-1838

Thresher RE, Koslow JA, Morison AK, Smith DC (2007) Depth-mediated reversal of the effects of climate change on long-term growth rates of exploited marine fish. Proc Natl Acad Sci USA 104:7461-7465

Tsukamoto K (2006) Spawning of eels near a seamount. Nature 439:929

> Wang $\mathrm{CH}$, Tzeng WN (2000) The timing of metamorphosis and growth rates of American and European eel leptocephali: A mechanism of larval segregative migration. Fish Res 46:191-205

Ware DM, Thomson RE (2005) Bottom-up ecosystem trophic dynamics determine fish production in the northeast. Pac Sci 308:1280-1284

- Watanabe YW, Ishida H, Nakano T, Nagai N (2005) Spatiotemporal decreases of nutrients and chlorophyll-a in the surface mixed layer of the western North Pacific from 1971 to 2000. J Oceanogr 61:1011-1016

Submitted: January 25, 2008; Accepted: August 14, 2008

Proofs received from author(s): December 3, 2008 